\title{
Mitochondrial DNA length variation in the cytochrome oxidase region of honey bee (Apis mellifera L)
}

\author{
MS Meusel *, RFA Moritz ** \\ Bayerische Landesanstalt für Bienenzucht, Burgbergstr 70, 8520 Erlangen, Germany
}

(Received 26 March 1991; accepted 14 January 1992)

Summary - Restriction fragment length polymorphism analysis of Apis mellifera capensis mitochondrial DNA detected a length variation in the cytochrome oxidase I and II gene region. A BCl I digest revealed a 430-bp insert not shared by $A m$ scutellata and $A$ m carnica.

Apis mellifera / mitochondrial DNA / length variation / cytochrome oxidase region

\section{INTRODUCTION}

Mitochondrial (mt) DNA has been shown to be a powerful tool in discriminating various subspecies of honey bees (Moritz et al, 1986; Smith, 1988; Smith and Brown, 1988). Due to differential selection analyzed within the male and female sex, selection dynamics in hybrid zones can be revealed. The technique is applicable to the Africanized honey bee problem in South and Central America. Smith et al (1989) and Hall and Muralidharan (1989) only found African mitotypes in Africanized honey bee populations and assumed that they spread exclusively via female lines. In terms of reproductive biology, this suggests limited fertile hybridization between African and European bees and competitive displacement of one species by the other. Genome-mitochondrial interactions could provide another explanation for the phenomenon of European mitotype elimination. Both explanations, which are theoretically possible, require rather extreme preconditions and are not supported by empirical field evidence from South America (Lobo et al, 1989; Moritz and Meusel, 1992). Another problem of the use of "specific" mt DNA markers is the rather poor knowledge on subspecies variability. Here we present a previously unpublished account of $\mathrm{mt}$ DNA length variation in the African honey bees subspecies Apis mellifera capensis.

\footnotetext{
* Correspondence and reprints: University of Natal, Department of Zoology and Entomology, PO Box 375, Pietermaritzburg 3200, South Africa.

** Present address: Technische Universität Berlin, Institut für Biologie, Franklinstr 28/29, D-1000

Berlin 10, Germany.
} 


\section{MATERIAL AND METHODS}

Thirty-three unrelated queens of managed colonies of the Cape honey bee ( $A \mathrm{~m}$ capensis) from various apiaries at the Cape of Good Hope were imported to Germany (between 1981 and 1989) and maintained as pure lineages by artificial insemination. Six colonies out of this stock supplied our samples for $\mathrm{mt}$ DNA analysis. Larvae of $5 \mathrm{~A} \mathrm{~m}$ scutellata colonies were collected in Johannesburg (Transvaal) and Ixopo (Natal), Republic of South Africa. A $m$ carnica larvae samples were taken from 9 domestic Bavarian hives.

Mt DNA was isolated from $0.5 \mathrm{~g}$ larvae (L5 stage) by differential centrifugation, protein extraction and ethanol precipitation (Moritz et al, 1986). Restriction enzyme digestion with $B C l$ I was carried out according to the supplier's (New England Biolabs) recommendations. Restriction fragments were end-labelled and separated on agarose gel $(1 \%)$ by electrophoresis $(60 \mathrm{~V}$, $35 \mathrm{~mA}$ ). The patterns were revealed by $X$-ray film documentation (Maniatis et al, 1982). EcoR $\mathrm{l} /$ Hind III digest of bacteriophage lambda DNA served as size standard.

The identity of the mitochondrial DNA fragment that contains the length variation was determined by radioactive probe hybridization (Southern, 1975). The 1.12 kilobase (kb) fragment of the $B c /$ l digest of $A m$ carnica mt DNA from the cytochrome oxidase-(CO) I and II gene region served as a probe (Crozier et al, 1989).

DNA was isolated following the above procedures, but omitting the mitochondria extraction steps as no cross-hybridization of the probe to nuclear DNA was found in preliminary experiments. Hybridization was carried out under standard techniques (Maniatis et al, 1982). The nylon membrane was exposed to X-ray film for documentation.

\section{RESULTS AND DISCUSSION}

All tested $A m$ mellifera subspecies showed a distinct restriction fragment length polymorphism (RFLP). Of particular interest is the 1.12-kb fragment in the $\mathrm{Bcl} I$ digest (fig 1) of carnica, which is $1.55 \mathrm{~kb}$ in capensis. This 430 basepair (bp) size variation is likely to be an insert and not the

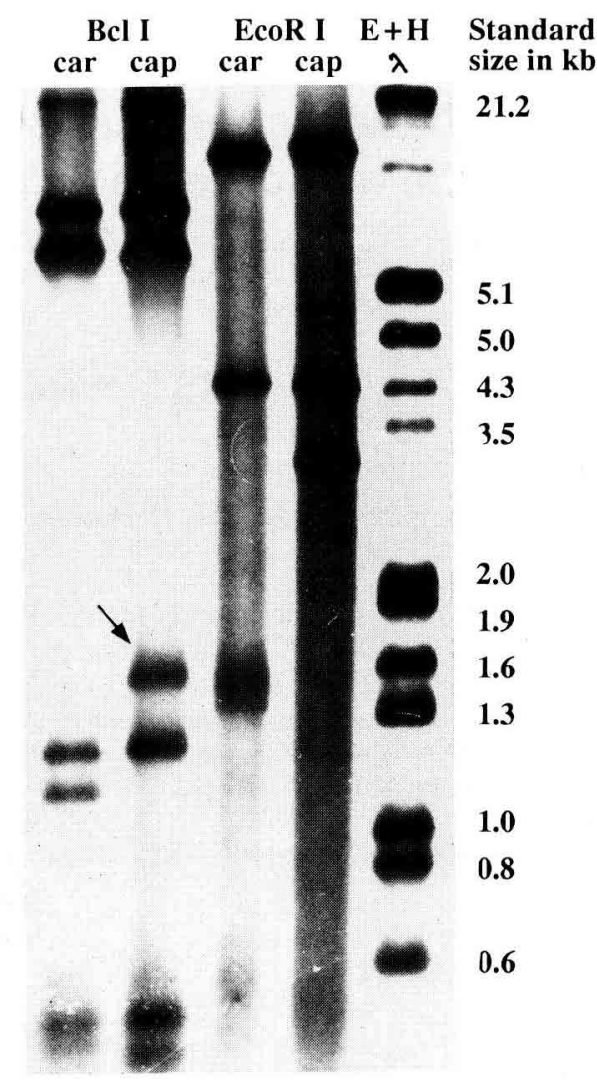

Fig 1. Autoradiograph of an $1 \%$ agarose gel showing $m t$ DNA restriction patterns from European (car, Apis mellifera carnica) and South African Cape (cap, $A m$ capensis) honey bees digested with the enzymes $B c l$ l and EcoR I. The arrow indicates the fragment including the length variation. Size standard: EcoR I/Hind III digest of Lambda DNA.

lack of a site because the 2 small fragments, which are adjacent in the restriction site map (Crozier et al, 1989) are clearly present. A $m$ scutellata has a 270-bp insert in the carnica fragment (Smith and Brown, 1988). These length variations may correspond to tandem repeat inserts (250 and $450 \mathrm{bp}$ ) found in recent sequence data of 


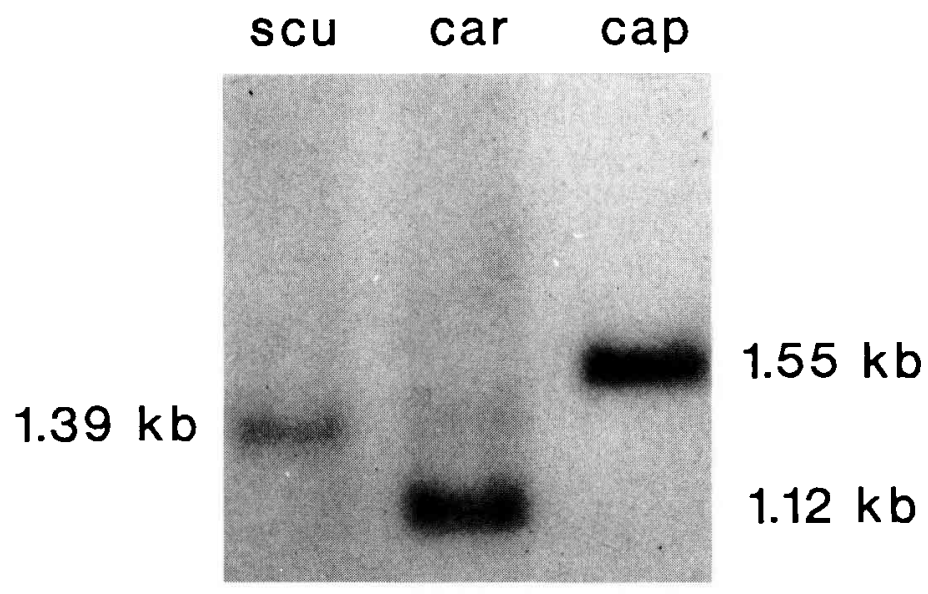

Fig 2. Autoradiograph of $\mathrm{mt}$ DNA Bcl l digest fragments from Apis mellifera scutellata (scu), A m carnica (car) and $A m$ capensis (cap) hybridized with the cloned probe $(1.12 \mathrm{~kb})$ of the $A m$ carnica $\mathrm{mt}$ DNA.

Cornuet et al (1991). The use of the cloned $B C l$ I DNA probe confirmed the different length of the fragments in question $(A \mathrm{~m}$ scutellata $1.39 \mathrm{~kb}, A \mathrm{~m}$ carnica $1.12 \mathrm{~kb}$, A $m$ capensis $1.55 \mathrm{~kb}$; fig 2) and their location within the $\mathrm{CO}-\mathrm{I}$ and $\mathrm{CO}-\mathrm{Il}$ gene region (Crozier et al, 1989) of the A m carnica $\mathrm{mt}$ DNA restriction map.

Mt DNA was used as a diagnostic tool for Africanized honey bees in South and Central America (Hall and Muralidharan, 1989; Smith et al, 1989). In addition to reservations we have on the basis of a study we recently conducted in Brazil (Moritz and Meusel, 1990, 1991), we suggest caution in the use of $\mathrm{mt}$ DNA as an indicator for the "African" honey bee until racial variation has been documented in detail. For example, European $A m$ mellifera revealed substantial variation with several size classes (Smith and Brown, 1990). Based on our study, we do not claim that the 430bp insert found in our samples is subspecies specific. However, our data show that $A m$ capensis and $A m$ scutellata may have distinct mitotypes, in contrast to previous reports (Sheppard and Huettel, 1987; Smith, 1988). Further studies on $\mathrm{mt}$ DNA of African bees may reveal many more RFLPs than found so far.

\section{ACKNOWLEDGMENTS}

This study was supported by the Deutsche Forschungsgemeinschaft. We are grateful to $\mathrm{RH}$ Crozier who supplied the $B C l$ I probe. M Hartmann and RM Crewe supplied the African honey bee queens.

Résumé - Variation de longueur de I'ADN mitochondrial dans la région de la cytochrome oxidase chez l'abeille (Apis mellifera L). L'analyse par les enzymes de restriction de l'ADNmt avec $B c / l$ a révélé chez l'abeille du Cap (A $m$ capensis) une variation de longueur de 430 paires de base (bp) dans un fragment de la région des cytochrome oxidases I et II par rapport à l'abeille européenne $A m$ carnica 
(fig 1). Chez l'abeille africaine $A m$ scutellata, cette variation de longueur porte sur $270 \mathrm{bp}$. Tant qu'aucune étude globale de génétique des populations ne sera faite sur des données suffisamment nombreuses, les polymorphismes trouvés jusqu'à présent ne pourront pas être utilisés comme diagnostic des races.

Apis mellifera / ADN mitochondrial / variation de longueur / région de la cytochrome oxidase

\section{Zusammentassung - Längenvariation der mitochondrialen DNA in der Cyto- chromoxidase-Region bei afrikanischen Honigbienen (Apis mellifera $L$ ). Restrik- tionsenzymanalyse der mitochondrialen DNA (Abb 1) mit $B c / l$ ergab bei der Kap- honigbiene ( $A$ m capensis) eine Längenva- riation von 430 Basenpaaren (bp) in einem Fragment der Cytochromoxidase I- und II- Region im Vergleich zur europäischen $A m$ carnica. Bei der afrikanischen $A$ m scutel- lata beträgt diese Längenvariation $270 \mathrm{bp}$. Solange keine umfassenden populations- genetischen Studien mit einer ausreichend großen Datenmenge durchgeführt worden sind, können die gefundenen Polymorphis- men nicht als rassenspezifisches Diagno- stikum eingesetz werden.}

Apis mellifera / mitochondriale DNA / Längenvariation / CytochromoxidaseRegion

\section{REFERENCES}

Cornuet JM, Garnery L, Solignac M (1991) Putative origin and function of the intergenic region between CO-I and CO-II of Apis mellifera L mitochondrial DNA. Genetics 128, 393-403

Crozier RH, Crozier YC, Mackinlay AG (1989) The CO-I and CO-II region of honey bee mitochondrial DNA: evidence for variation in insect mitochondrial evolutionary rates. $\mathrm{Mol}$ Biol Evol 6, 399-411

Hall HG, Muralidharan K (1989) Evidence from mitochondrial DNA that African honey bees spread as continuous maternal lineages. $\mathrm{Na}$ ture (Lond) 339, 211-213

Lobo JA, Del Lama MA, Mestriner MA (1989) Population differentiation and racial admixture in the Africanized honey bee (Apis mellifera L). Evolution 43, 794-802

Maniatis T, Fritsch EF, Sambrook J (1982) Molecular Cloning: A Laboratory Manual. Cold Spring Harbor Laboratory, Cold Spring Harbor, New York

Moritz RFA, Hawkins CF, Crozier RH, Mackinlay AG (1986) A mitochondrial DNA polymorphism in honey bees (Apis mellifera L). Experientia 42, 322-324

Moritz RFA, Meusel M (1990) The use of nuclear and mitochondrial DNA variation in the Africanized honey bee problem. Proc 32 nd Int Congr Apimondia, Rio de Janeiro, p 69

Moritz RFA, Meusel M (1992) Mitochondrial gene frequencies in Africanized honeybees (Apis mellifera L): theoretical model and empirical evidence. J Evol Biol 5, 71-81

Sheppard WS, Huettel MD (1987) Subspecific identification of honey bees using mitochondrial DNA analysis. $A m B e e J$ 127, 851

Smith DR (1988) Mitochondrial DNA polymorphisms in five Old World subspecies of honey bees and in New World hybrids. In: Africanized Honey Bees and Bee Mites (Needham GR, Page RE, Delfinado-Baker M, Bowman CE, eds) Ellis Horwood, Chichester, 302-312

Smith DR, Brown WM (1988) Polymorphisms in mitochondrial DNA of European and Africanized honey bees (Apis mellifera). Experientia 44, 257-260

Smith DR, Taylor OR, Brown WM (1989) Neotropical Africanized honey bees have African mitochondrial DNA. Nature (Lond) 339, 213215

Smith DR, Brown WM (1990) Restriction endonuclease cleavage site and length polymorphisms in mitochondrial DNA of Apis mellifera mellifera and $A m$ carnica (Hymenoptera: Apidae). Ann Entomol Soc Am 83, 81-88

Southern EM (1975) Detection of specific sequences among DNA fragments separated by gel electrophoresis. J Mol Biol 98, 503-517 